Fife, D. T., I. L. Pollet, G. J. Robertson, M. L. Mallory, and D. Shutler. 2015. Apparent survival of adult Leach's Storm-petrels (Oceanodroma leucorhoa) breeding on Bon Portage Island, Nova Scotia. Avian Conservation and Ecology 10(2): 1. http://dx.doi.org/10.5751/ACE-00771-100201 Copyright (C) 2015 by the author(s). Published here under license by the Resilience Alliance.

Research Paper

\title{
Apparent survival of adult Leach's Storm-petrels (Oceanodroma leucorhoa) breeding on Bon Portage Island, Nova Scotia
}

\author{
Danielle T. Fife ${ }^{1}$, Ingrid L. Pollet ${ }^{1}$, Gregory J. Robertson ${ }^{2}$, Mark L. Mallory ${ }^{1}$ and Dave Shutler ${ }^{1}$ \\ ${ }^{1}$ Acadia University, ${ }^{2}$ Wildlife Research Division, Environment Canada
}

\begin{abstract}
Populations of Leach's Storm-petrel (Oceanodroma leucorhoa; hereafter storm-petrel), one of the most widespread procellariiform seabirds in the world, appear to be declining in many parts of their breeding range. As part of a regional effort to assess status of storm-petrel colonies in eastern North America, we estimated apparent survival and recapture probabilities from 2009 to 2014 for adults on Bon Portage Island ( $\left.43^{\circ} 28^{\prime} \mathrm{N}, 65^{\circ} 44^{\prime} \mathrm{W}\right)$, located off the southwestern coast of Nova Scotia, Canada. Mean annual survival estimated for this colony was low $(0.78 \pm 0.04)$ compared with other procellariiforms, e.g., $>0.90$ for many albatrosses and petrels. Storm-petrels that were fitted with very high frequency (VHF) radio tags had an average of $0.11 \pm 0.05$ ( $95 \%$ confidence interval $[\mathrm{CI}]=0.01$ to 0.21 ) higher survival probabilities than those that were not, possibly because VHF tags were attached to known, established breeders. There was weak evidence that survival was reduced by an average of $0.07 \pm 0.04$ for storm-petrels in study plots that were occupied by Herring Gulls (Larus argentatus) and their chicks; however, this result was not statistically significant (95\% CI: -0.15 to 0.02). Low adult survival is an early indication that this important colony may be under stress. However, further work is needed to determine if the colony is indeed declining and, if so, to determine the cause(s) of the decline so that they may be addressed.
\end{abstract}

\section{Survie apparente des Océanites cul-blanc (Oceanodroma leucorhoa) adultes nicheurs sur l'île Bon Portage, Nouvelle-Écosse}

RÉSUMÉ. Les populations d'Océanite cul-blanc (Oceanodroma leucorhoa; ci-après océanite), une des espèces de Procellariiformes les plus répandues dans le monde, semblent en diminution dans de nombreuses parties de son aire de nidification. Dans le cadre d'un effort régional visant à évaluer le statut des colonies d'océanites dans l'est de l'Amérique du Nord, nous avons estimé la survie apparente et la probabilité de recapture d'adultes sur l'île Bon Portage ( $43^{\circ} 28^{\prime}$ N., $65^{\circ} 44^{\prime}$ O.), sise au large de la côte sud-ouest de la Nouvelle-Écosse, Canada, de 2009 à 2014. La survie annuelle moyenne estimée pour cette colonie était faible $(0,78 \pm 0,04)$ comparativement à celle d'autres Procellariiformes, soit > 0,90 pour nombre d'albatros et de pétrels. Les océanites équipés d'émetteurs radio VHF ont obtenu une probabilité de survie plus élevée de $0,11 \pm 0,05$ ( $95 \%$ intervalle de confiance $[\mathrm{IC}]=0,01$ à 0,21$)$ en moyenne que ceux qui ne portaient pas d'émetteurs, peut-être parce que les émetteurs ont été posés sur des adultes pour lesquels le statut de reproducteur était déjà connu. Il y avait une faible évidence de survie réduite de 0,07 \pm 0,04 en moyenne pour les océanites qui occupaient des parcelles dans lesquelles se trouvaient aussi des Goélands argentés (Larus argentatus) et leurs poussins; toutefois, ce résultat n'était pas significatif sur le plan statistique $(95 \% \mathrm{IC}=-0,15$ à 0,02$)$. La faible survie des adultes est un signe précurseur que cette colonie d'importance est exposée à des contraintes. Par ailleurs, d'autres travaux sont nécessaires pour de déterminer si la colonie diminue réellement et, le cas échéant, de trouver les causes de la diminution afin d'y remédier.

Key Words: apparent survival; capture-mark-recapture (CMR); Leach's Storm-petrel; Oceanodroma leucorhoa; predation; seabird; VHF tags

\section{INTRODUCTION}

For long-lived seabirds, adult survival is one of the most important demographic traits for maintaining viable populations and should remain relatively high and constant despite natural environmental variability (Clobert and Lebreton 1991, Erikstad et al. 1998, Cubaynes et al. 2011). Therefore, variability in seabird population size is often associated with reproductive output, because breeding adults are able to reallocate investment from reproductive effort to self-maintenance when conditions, e.g., weather, food supply, are poor (Erikstad et al. 1998, Cubaynes et al. 2011, Hovinen et al. 2014). Conversely, slow reproductive rates and high breeding site fidelity of seabirds mean that their populations are sensitive to even minor changes in adult survival; consistently low or highly variable survival probabilities are signs that a population is under stress and at a greater risk of rapid decline (Weimerskirch and Jouventin 1987, Wooller et al. 1992).

Burrow-nesting species, e.g., many petrels, can be quite cryptic and difficult to monitor; therefore, the risk of dramatic population declines going undetected can be greater than that for more accessible species. Leach's Storm-petrel (Oceanodroma leucorhoa, hereafter storm-petrel) is a small ( $\sim 45-\mathrm{g})$, long-lived seabird that nests in burrows on offshore islands. Breeding adults leave and return to their burrows at night, and may remain at sea foraging for several days (Pollet et al. 2014a). Birds from Atlantic colonies winter at sea off of eastern South America and southwestern Africa (Huntington et al. 1996, Pollet et al. 2014b). It is the most abundant tubenose species (Order: Procellariiformes) breeding in 
the Northern Hemisphere, with more than 10 million breeding pairs, roughly a third of which are found within a single colony on Baccalieu Island, Newfoundland, Canada (Fig. 1; Sklepkovych and Montevecchi 1989, Huntington et al. 1996, Robertson et al. 2006a).

Fig. 1. Location of the study site, Bon Portage Island, Nova Scotia, Canada (star) and other nearby Leach's Storm-petrel (Oceanodroma leucorhoa) colonies mentioned in text. (1) Baccalieu Island, Newfoundland; (2) Gull Island, Newfoundland; (3) Great Island, Newfoundland; (4) Country Island, Nova Scotia; (5) Kent Island, New Brunswick; (6) Seal Island, Nova Scotia.

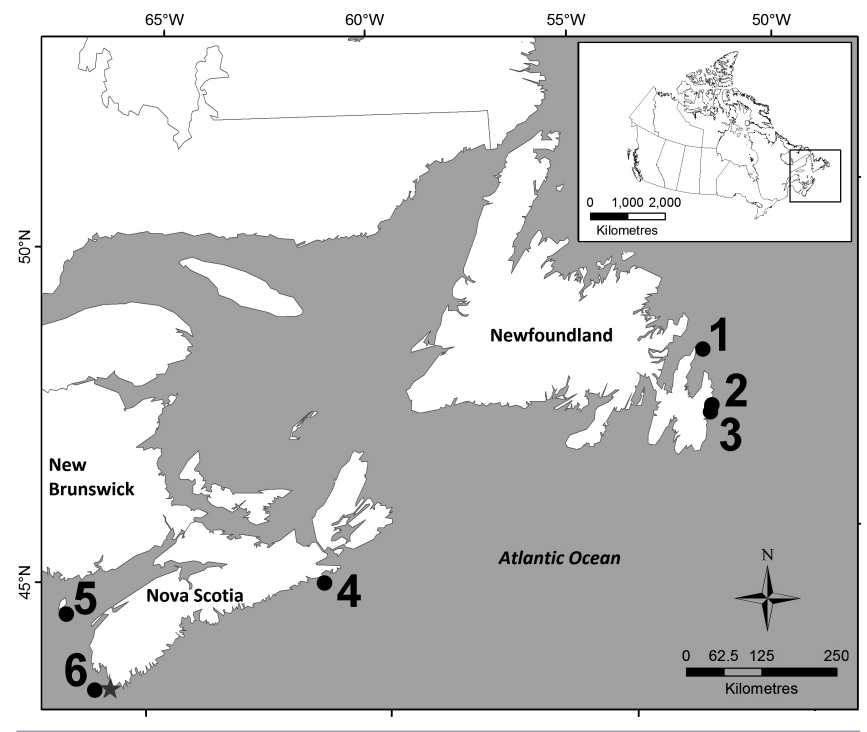

Populations of storm-petrels from some Atlantic colonies have recently shown steep declines (Robertson et al. 2006a, Newson et al. 2008) and even complete collapses, e.g., at Seal Island, Nova Scotia (Fig. 1) due to introductions of predators, including rats (Rattus spp.) and cats (Felis catus, Huntington et al. 1996). Between 1979 and 2011, the large colony at Great Island, Newfoundland (Fig. 1), declined by nearly 55\% (Wilhelm et al. 2015), possibly because of the high number of predatory Great Black-backed Gulls (Larus marinus) and Herring Gulls (Larus argentatus) breeding on the island. Similarly, Great Skua (Stercorarius skua) predation has contributed to a $54 \%$ decline of a colony in the St. Kilda island archipelago, Scotland, the largest colony in the United Kingdom (Newson et al. 2008). Preliminary analyses of a 2013 population census of the huge Baccalieu Island colony suggest that burrow densities were reduced in forest habitats, but not in fern or grass/herb habitats, compared with densities reported in the 1980s. However, further analyses, e.g., changes in densities relative to changes in habitat types, are required to determine the extent of these changes (Canadian Wildlife Service, unpublished data).

Although estimates of abundance are an important component of any monitoring program (Major and Chubaty 2012, Sutherland and Dann 2012, Wilhelm et al. 2015), estimates of adult survival probabilities can be more precise and, in the case of burrow-nesting species, easier to obtain. For these reasons, and in light of declines at multiple colonies, the aim of this study was to estimate annual survival and recapture probabilities for adult storm-petrels breeding on Bon Portage Island from 2009 to 2014. Given apparent effects that gulls and other predators have had at other colonies, we compared survival probabilities between plots that had nesting gulls and those that did not. We predicted that storm-petrels nesting in plots with gulls would have lower survival probabilities than those nesting in plots without gulls.

Another factor that we considered was whether attachment of very high frequency (VHF) radio tags influenced survival probabilities. Nearly $10 \%(n=83)$ of the storm-petrels used in this study received a VHF tag for a separate study to monitor within-breeding season activity around the colony (I. L. Pollet, unpublished data). Although VHF tags used on birds are generally small (Burger and Schaffer 2008), they could affect return rates by impeding, for example, mobility (Reynolds et al. 2004). Moreover, extended handling time required for attaching the devices could cause additional stress and deter adults from returning to their burrows. However, because return rates of storm-petrels at this colony were not influenced by attachment of geolocators (Global Location Sensing [GLS]; Pollet et al. 2014b), which were heavier than VHF tags, we predicted that VHF tags would not have an effect on survival probabilities.

\section{METHODS}

\section{Study site}

Bon Portage Island $\left(43^{\circ} 28^{\prime} \mathrm{N}, 65^{\circ} 44^{\prime} \mathrm{W}\right)$ is $\sim 0.5 \times 3 \mathrm{~km}$ and lies $\sim 3 \mathrm{~km}$ off the southwestern shore of Nova Scotia, Canada (Fig. 1). A population census in 2001 estimated that about $50,000(95 \%$ confidence interval $[\mathrm{CI}]=37,541$ to 58,944 ) pairs of storm-petrels bred on the island (D. Shutler, unpublished data). This estimate was obtained in late August by reaching into all burrows within $832.5-\mathrm{m} \times 10-\mathrm{m}$ plots along east-west transects that crossed the island. Transects had random starting points along the shore, and plots were $30 \mathrm{~m}$ apart, starting $30 \mathrm{~m}$ from the edge of suitable habitat. Oxley (1999) used similar census methods. However, because of uncertainty related to large sampling error $( \pm \sim 10,000)$, it is difficult to assess actual population size, or moreover, detect anything but gross trends with successive censuses.

For our study, storm-petrels were monitored in twelve $12-\mathrm{m} \times 12$ m quadrats, spaced $\sim 10 \mathrm{~m}$ apart and situated primarily within forested areas; however, two of the plots were in more open habitat with only a few standing dead trees. These two plots have each year been occupied by 3-4 pairs of Herring Gulls and their chicks (I. L. Pollet, personal observation). Each plot contained an average of 29.1 (range: 15-53) uniquely numbered, marked burrows. Over the duration of this study a mink (Neovison vison) was spotted only once on the island and a rat (Rattus norvegicus) may have been sighted, but this was not confirmed. Therefore, to our knowledge, there were few introduced or invasive mammalian predators on the island (I. L. Pollet, unpublished data).

\section{Capture-mark-recapture of adults}

Banding of adults began in 2009 and continued until 2014; however, early in the study, several adults were banded in burrows outside the current study area. These burrows were not monitored as routinely as those within the study area; therefore, to reduce bias in survival estimates, these burrows were not included in the present analysis. The sample size of birds within current plots from 2009 is therefore smaller than that of 2010 onward. Nesting 
adults were captured over a period ranging between 5 and 9 weeks, from approximately late June to August in each year. During incubation, burrows were checked no more than twice (Pollet et al. 2014a). Adults were caught opportunistically or with one-way traps placed at burrow entrances and were extracted from burrows by hand. At initial capture, adults were banded with a numbered Canadian Wildlife Service stainless steel or incoloy leg band.

From 2010 to 2013, a random subset of active breeders $(n=83)$ received VHF tags, which were attached to their backs with tape and glue. VHF tags weighed $0.29 \mathrm{~g}(<0.7 \%$ of average adult body mass) and measured $10 \times 4 \times 2 \mathrm{~mm}$, with an external aerial measuring $180 \times 0.2 \mathrm{~mm}$ (I. L. Pollet, unpublished data). These birds were distinguished in the analysis from those that did not receive a VHF tag in any year. VHF tags lasted $<60 \mathrm{~d}$ and would have either stopped working or fallen off during the nonbreeding season; therefore, they would not have aided in recapture of birds in the following breeding season. In 2012 and 2013, a smaller proportion of birds (also active breeders; $n=13$ in 2012 and $n=$ 22 in 2013) received GLS, which were affixed to their backs either with tape and glue or with sutures. Including attachment material, GLS weighed $1.3 \mathrm{~g}(<3 \%$ of the average mass of adult stormpetrels) and measured $21.9 \times 7.9 \times 3.8 \mathrm{~mm}$ (Pollet et al. 2014b). Chicks of storm-petrels with back-sutured GLS had lower growth rates compared with those of controls, but there was no difference in return rates, mass, or fledging success of storm-petrels with versus without GLS (see Pollet et al. 2014a, 2014b). Therefore, we did not consider GLS effects, nor did we exclude birds with GLS from the analysis. Accurate sex and age data are difficult and expensive to obtain for storm-petrels and were not included in this study; however, we recognize that these factors, in addition to attachment of GLS, could have influenced survival (e.g., Robertson et al. 2006b, Sanz-Aguilar et al. 2009).

\section{Survival analyses}

Data were collected using traditional capture-mark-recapture (CMR) methods and analyzed using Program MARK (Lebreton et al. 1992, White and Burnham 1999). Apparent survival ( $\phi)$ was estimated as the probability of surviving from one sampling occasion, i.e., breeding season, to the next. Estimates of apparent survival are generally biased below true survival because mortality and emigration are confounded without additional information on, for example, dead recoveries or recaptures from outside the study area (Kendall et al. 2013). Recapture probability ( $p$ ) was estimated as the probability of being recaptured at each occasion (Lebreton et al. 1992). A bird was considered encountered if it was captured at least once during the five to nine weeks that burrows were examined each summer. Encounter histories displaying initial captures and recaptures for each bird were generated using the RMark (Laake 2013) package in R 3.2.1 (R Development Core Team 2014). Storm-petrels were separated in the encounter history file into four groups based on whether or not they were nesting in plots with gulls and whether or not they received a VHF tag at any point in the study; i.e., if a bird received a VHF tag in any year, it was treated in the analysis as having a VHF tag in all years. Because of the length of the capture period, robust design models were considered, but multiple within-year recaptures of birds were few and the data were too sparse for a meaningful analysis using the robust design (Kendall et al. 1997).

\section{Model selection}

The global model used in the analysis was based on the CormackJolly-Seber model, an open-population model where $\phi$ and $p$ vary over time (Lebreton et al. 1992), but we included additional parameters for the gull and VHF effects. Because of sparse data, especially in plots where gulls were present, we did not consider the fully saturated model (i.e., $\phi_{\text {gulls*VHF*time }}, p_{\text {gulls*VHF*time }}$ ) as a suitable global model. Specifically, we considered the following: (1) Given that this is a burrow-nesting species, it was unlikely that presence of gulls would affect recapture probabilities. (2) An interactive effect of gulls and VHF tags on survival probabilities would be difficult to estimate because of the relatively small number of plots with gulls and would be difficult to interpret. (3) Estimating time-specific effects of gull presence on survival probabilities would be difficult and would not be expected to vary over time because of the consistent presence of gulls on these plots. We retained the interactive effect of VHF tags and time on survival because birds did not have VHF tags in all years. Therefore, our starting model was $\phi_{\text {gulls }}+\mathrm{VHF}^{*}$ time,$p_{\mathrm{VHF} * \text { time }}$. We used this model structure for survival probabilities and compared support for all reduced forms of $p_{\mathrm{VHF} * \text { time }}$. The resulting bestsupported model for $p$ was retained to subsequently model

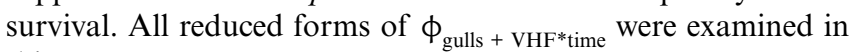
this step.

Akaike's Information Criterion adjusted for small sample size $\left(\mathrm{AIC}_{\mathrm{c}}\right)$ was used to select among competing models. In this information-theoretic approach, models with a $\triangle \mathrm{AIC}_{\mathrm{c}}$ (i.e., the difference between the highest supported model and each of the other models) $\leq 2$ are considered to have similar support within a candidate model set (Burnham and Anderson 2002). If multiple models were given similar support, model-averaging was used to produce annual estimates that were based on the full candidate set of models and weighted by the overall support for each model (note that the sum of $\mathrm{AIC}_{\mathrm{c}}$ weights across the model set $=1$; Burnham and Anderson 2002). Variance component analysis of the global model provided an average survival estimate and an estimate of the amount of time-dependent process variation (i.e., the difference between the total variance and the sampling variance; $\sigma^{2}$ ) in the data (Burnham et al. 1987).

\section{Goodness of fit}

We tested for violations of Cormack-Jolly-Seber assumptions (Lebreton et al. 1992, Pollock and Alpizar-Jara 2005) in the global model using RELEASE, a built-in component of Program MARK. The two primary tests implemented in RELEASE, test 3 and test 2, essentially look for evidence of heterogeneity in survival and recapture probabilities, respectively, among individuals, (e.g., because of transiency or trap effects, Pradel et al. 1997, 2005). Because violations of assumptions may be difficult to detect with few sampling occasions, we included transiency models (described by Pradel et al. 1997) in our model set as an additional test for an effect of transiency (reduced apparent survival of birds after their first capture) on survival probabilities. We then performed likelihood ratio tests between models with a transiency effect on survival probabilities and comparable nested models containing no transiency effect. The variance inflation factor $(\hat{c})$ was estimated using the median $\hat{c}$ method, derived from the global model, implemented in MARK. If an adjustment to $\hat{c}$ was made, model selection was based on the Quasi-Akaike's 
Information Criterion (QAIC $)$, which assigns further penalty for the number of parameters in a model (Anderson et al. 1994).

\section{RESULTS}

In total, 709 adults were banded from 2009 to 2014, with a total of 860 recaptures during that time. Table 1 shows a reduced marray that indicates when birds, separated into groups based on gull presence and VHF tags, were seen again for the first time after release. For example, of the 283 individuals in total that were released in 2010, 38\% were seen again for the first time in 2011 and $54 \%$ were seen at least once in subsequent years. The small number of individuals banded in 2009 ( $n=13$ across all groups) explains the large confidence intervals surrounding $\phi$ values for 2009-2010.

Table 1. Reduced m-array showing when and how many adult Leachapo's Storm-petrels (Oceanodroma leucorhoa) were recaptured for the first time after initial release at Bon Portage Island, Nova Scotia, Canada, 2009 to 2014. Note that "\# released" at a particular occasion (Year released) includes stormpetrels newly banded and those that were previously banded and recaptured at that occasion. Storm-petrels were separated into those nesting in plots with (gulls, 10 plots) and without (gulls, 2 plots) Herring Gulls (Larus argentatus) and those with (very high frequency [VHF]) and without (no VHF) VHF tags. Sample size of storm-petrels at initial capture is shown in parentheses. Numbers of storm-petrels from each group were pooled for the initial analysis.

\begin{tabular}{|c|c|c|c|c|c|c|c|}
\hline \multirow[t]{2}{*}{ Year released } & \multirow[t]{2}{*}{ \# released } & \multicolumn{6}{|c|}{ \# recaptured for first time after release } \\
\hline & & 2010 & 2011 & 2012 & 2013 & 2014 & Total \\
\hline \multicolumn{8}{|c|}{ no gulls, no VHF (n = 515) } \\
\hline 2009 & 11 & 6 & 2 & 0 & 0 & 0 & 8 \\
\hline 2010 & 188 & & 63 & 20 & 6 & 7 & 96 \\
\hline 2011 & 145 & & & 50 & 16 & 7 & 73 \\
\hline 2012 & 150 & & & & 75 & 16 & 91 \\
\hline 2013 & 259 & & & & & 114 & 114 \\
\hline \multicolumn{8}{|c|}{ no gulls, VHF (n = 69) } \\
\hline 2009 & 1 & 1 & 0 & 0 & 0 & 0 & 1 \\
\hline 2010 & 41 & & 24 & 6 & 1 & 0 & 31 \\
\hline 2011 & 39 & & & 22 & 6 & 0 & 28 \\
\hline 2012 & 35 & & & & 20 & 4 & 24 \\
\hline 2013 & 33 & & & & & 12 & 12 \\
\hline \multicolumn{8}{|c|}{ gulls, no VHF $(\mathrm{n}=111)$} \\
\hline 2009 & 5 & 2 & 0 & 0 & 0 & 0 & 2 \\
\hline 2010 & 46 & & 15 & 1 & 1 & 2 & 19 \\
\hline 2011 & 38 & & & 12 & 4 & 0 & 16 \\
\hline 2012 & 23 & & & & 8 & 4 & 12 \\
\hline 2013 & 42 & & & & & 16 & 16 \\
\hline \multicolumn{8}{|c|}{ gulls, VHF $(n=14)$} \\
\hline 2009 & 1 & 0 & 0 & 1 & 0 & 0 & 1 \\
\hline 2010 & 8 & & 6 & 1 & 0 & 0 & 7 \\
\hline 2011 & 7 & & & 3 & 1 & 1 & 5 \\
\hline 2012 & 5 & & & & 2 & 0 & 2 \\
\hline 2013 & 7 & & & & & 4 & 4 \\
\hline
\end{tabular}

We did not find significant sources of heterogeneity in recapture and survival probabilities considered together (test $2+$ test 3 : $\chi_{34}^{2}=21.1, p=0.96$ ) or considered separately (test $2: \chi_{11}^{2}=13.3$, $p=0.27$; test $\left.3: \chi_{23}^{2}=7.8, p>0.99\right)$. In accordance with results from RELEASE, overdispersion was minimal ( $\hat{c}=1.09)$, but was adjusted in the model selection. We found no support for transiency models (QAIC weights < 0.0001). Moreover, likelihood ratio tests comparing two simple transiency models $\left(\phi_{\text {transiency }}, p_{\text {time }}\right.$ and $\left.\phi_{\text {transiency }}, p\right)$ with those without a transiency effect were not significant $\left(\chi_{1}^{2}=0.1, p=0.82\right.$, and $\chi_{1}^{2}=0.4, p=$ 0.52 , respectively). Therefore, if there were transient birds in our study, we did not find evidence to suggest that their presence influenced the analysis.

\section{Survival analyses}

A model with only a VHF effect on recapture probability had the highest support $(\mathrm{QAIC}$ weight $=0.74)$ among recapture models; therefore, we modeled survival probability with recapture probability constrained only by the VHF variable (Table 2). The

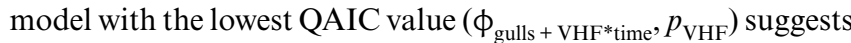
that in both the VHF and no VHF groups, storm-petrels that were in plots without gulls had higher survival than those in plots with gulls. In addition, compared with storm-petrels that were not fitted with a VHF tag, those with a VHF tag had higher survival in the first three occasions of the study, but lower survival in the last two occasions. However, this model estimated survival poorly (i.e., > 0.99) for birds with VHF tags in both the gull and no gull groups in the first interval (2009 to 2010).

Table 2. Modeling effects of gull presence and very high frequency (VHF) tags on apparent survival $(\phi)$ and recapture $(p)$ probabilities of adult Leach's Storm-petrels (Oceanodroma leucorhoa) on Bon Portage Island, Nova Scotia, Canada, 2009 to 2014 (values corrected for minor overdispersion; $\hat{c}=1.09$ ). $\triangle \mathrm{QAIC}_{\mathrm{c}}$ is the difference between a given model and the model with the lowest Quasi-Akaike's Information Criterion (QAIC) value, and $K$ is the number of parameters. Only models with QAIC weights $\geq 0.01$ are included in this table. Note that 2 out of 12 plots were occupied by 3-4 pairs of Herring Gulls (Larus argentatus) and their chicks.

\begin{tabular}{|c|c|c|c|c|c|}
\hline Model & $\Delta \mathrm{QAIC}_{\mathrm{c}}$ & $\begin{array}{l}\text { QAIC }_{c} \\
\text { weights }\end{array}$ & Likelihood & $K$ & Deviance \\
\hline $\begin{array}{l}\phi_{\text {gulls }+\mathrm{VHF} * \text { time }}, p_{\mathrm{VHF}} \\
\phi_{\mathrm{VHF} * \text { time }}, p_{\mathrm{VHF}} \\
\phi_{\text {gulls }+\mathrm{VHF}+\text { time }}, \\
p_{\mathrm{VHF}} \\
\phi_{\text {gulls }+\mathrm{VHF}}, p_{\mathrm{VHF}} \\
\phi_{\mathrm{VHF}+\text { time }}, p_{\mathrm{VHF}} \\
\phi_{\text {gulls }+\mathrm{VHF} * \text { time }}, \\
p_{\mathrm{VHF} * \text { time }} \\
\phi_{\text {gulls }+\mathrm{VHF} * \text { time }}, p \\
\phi_{\mathrm{VHF}}, p_{\mathrm{VHF}} \\
\phi_{\text {gulls }}, p_{\mathrm{VHF}} \\
\phi_{\text {gulls }+ \text { time }}, p_{\mathrm{VHF}}\end{array}$ & $\begin{array}{l}3.89 \\
4.55 \\
5.83 \\
6.31\end{array}$ & $\begin{array}{l}0.05 \\
0.03 \\
0.02 \\
0.01\end{array}$ & $\begin{array}{l}0.14 \\
0.10 \\
0.05 \\
0.04\end{array}$ & $\begin{array}{c}12 \\
4 \\
4 \\
8\end{array}$ & $\begin{array}{l}121.11 \\
138.03 \\
139.31 \\
131.69\end{array}$ \\
\hline
\end{tabular}

Given that there was similar support for more than one model, we model-averaged estimates of both $\phi$ and $p$ (Table 2, Fig. 2). Model-averaged survival probabilities were highest in all years for birds that were in plots without gulls and fitted with VHF tags. In general, birds fitted with VHF tags had higher survival than those without tags, except from 2012 to 2013, when survival probability in all groups was similar (Fig. 2). Model-averaged 
recapture probabilities were higher for birds with VHF tags (VHF: $p=0.68 \pm 0.06,95 \% \mathrm{CI}=0.55$ to 0.79 ; no VHF $: p=0.55 \pm 0.03$, $95 \% \mathrm{CI}=0.49$ to 0.61 ).

We calculated model-averaged effect sizes, as well as their associated standard errors (SEs), of both the gull and VHF tag variables using models that contained single variable or additive effects only; models with interactions were excluded from this process to avoid confounding effects of multiple variables. Within the selected models, mean effect sizes and SEs for each variable were calculated and then weighted by respective QAIC weights (rescaled to 1) and transformed to the probability scale. Based on this, presence of gulls reduced $\phi$ by $0.07 \pm 0.04$, although the confidence interval bounded zero $(95 \% \mathrm{CI}=-0.15$ to 0.02$)$, whereas attachment of VHF tags increased $\phi$ by $0.11 \pm 0.05(95 \%$ $\mathrm{CI}=0.01$ to 0.21 ). Mean survival estimated from variance component analysis was $0.78 \pm 0.04$. Variance-component analysis also indicated that there was significant time-dependent process variance $\left(\sigma^{2}=0.01,95 \% \mathrm{CI}=0.01\right.$ to 0.04$)$.

Fig. 2. Model-averaged annual survival estimates $( \pm S E)$ from 2009 to 2013 for adult Leach's Storm-petrels (Oceanodroma leucorhoa) on Bon Portage Island, Nova Scotia, Canada. No estimate is given for 2013-2014 because only a return rate can be estimated for the final interval. Birds were grouped into those nesting in plots with or without Herring Gulls and with or without VHF tags. Note that the particularly large SEs in 2009-2010 are because of small sample sizes of storm-petrels banded in 2009 .

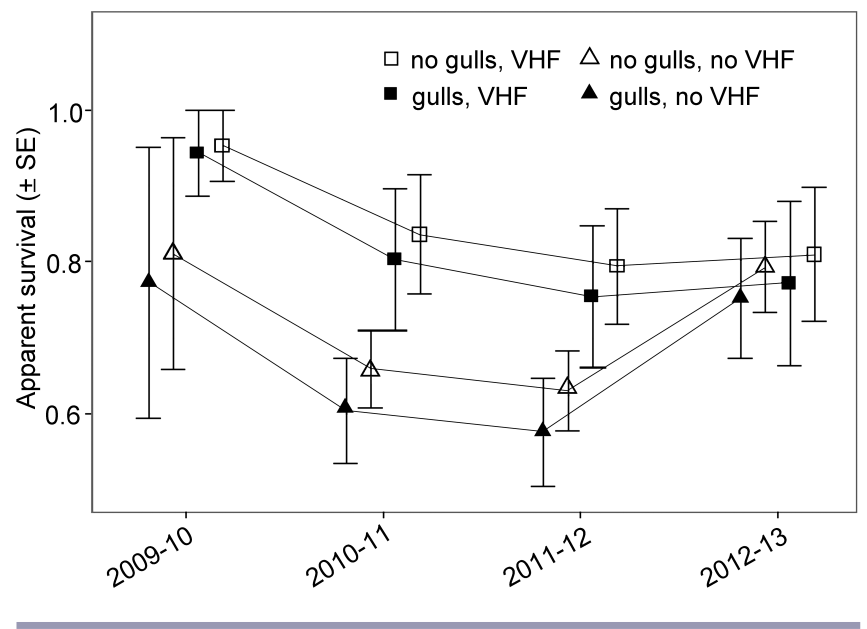

\section{DISCUSSION}

Mean annual survival of adult storm-petrels on Bon Portage Island was low compared with that of other storm-petrel species (e.g., Beck and Brown 1972, Zabala et al. 2010; survival for tubenoses is typically $>0.90$, Appendix 2 in Schreiber and Burger 2001) and even compared with earlier estimates from another storm-petrel colony (Huntington et al. 1996). There was also evidence that survival probabilities from our study varied annually. Survival of adult storm-petrels from a colony on Gull Island, Newfoundland (Fig. 1), also varied over time and was low, on average $\sim 0.80$ from 2003 to 2013 (A. Hedd, unpublished data). Similarly, on Kent Island, New Brunswick (Fig. 1), mean survival was $\sim 0.79$ from 1953 to 1994 (Huntington et al. 1996). Seabirds are usually characterized as having high adult survival probabilities that should be quite resilient to environmental variability. Maintenance of high survival probabilities is possible in part because they can reduce reproductive effort, or even skip breeding in unfavorable years to focus instead on selfpreservation (Cubaynes et al. 2011, Zabala et al. 2011). However, given their slow reproductive rates, even minor reductions in adult survival can have pronounced effects on seabird populations (Wooller et al. 1992), which are slow to recover after episodes of high adult mortality (Weimerskirch and Jouventin 1987). Moreover, typically high breeding site fidelity, i.e., probability of returning to the same breeding location, among seabirds means that they are unlikely to relinquish breeding sites even if conditions are poor in multiple years (Schreiber and Burger 2001). Therefore, losses to the population accrued as consequences of reduced survival and/or skipped breeding are likely to persist with ongoing environmental perturbations (see Gaston 2011 and references therein).

Something to be cognizant of in survival and other CMR studies is investigator disturbance, which can influence reproductive success and potentially lead to nest abandonment (Blackmer et al. 2004, Carey 2009; but see O'Dwyer et al. 2006, Fiske et al. 2013). Burrows on Bon Portage Island were visited only twice during incubation, which should be associated with infrequent abandonment (Blackmer et al. 2004). Once chicks had hatched, burrows were monitored approximately once each week to quantify chick growth rates and other parameters associated with breeding success. During this time, adults are rarely present in burrows during the day; therefore, disturbance of adults was minimal(I. L. Pollet, personal observation). In cases where certain adults had yet to be recaptured in a particular breeding season, one-way traps were placed at their burrow entrances, which may have influenced their willingness to return to those burrows in subsequent years. As a rough gauge of the effects of repeated handling of storm-petrels on Bon Portage Island, a burrowswitching rate was calculated by dividing the number of adults that switched burrows from one year to the next by the total number of adults recaptured between those two years. This rate was $\sim 8.1 \%$ per year, and almost all moves $(n=55)$ were within $<$ $1 \mathrm{~m}$ of the previous burrow (I. L. Pollet, unpublished data). We cannot completely exclude the possibility that birds simply emigrated to another location, either outside of the study plots on Bon Portage Island or even to other islands. However, reported breeding site fidelity of storm-petrels is high (0.92-0.96; Morse and Buchheister 1979, Huntington et al. 1996); therefore, bias in survival probabilities because of emigration should be minimal.

\section{Effects of VHF tags on survival}

The burden of carrying tracking devices can be energetically costly, even if they are small compared with the size of a bird. For example, corticosterone levels were elevated and tail growth reduced in Thin-billed Prions (Pachyptila belcheri) fitted with GLS that were $<1 \%$ of their body mass (Quillfeldt et al. 2012). These sorts of responses can, in turn, have consequences for survival (Reynolds et al. 2004). Surprisingly, we found that stormpetrels with VHF tags had, on average, $\sim 10 \%$ higher survival than those without tags. This might be partially because of an influence of VHF tags on recapture probabilities. There appears 
to be strong evidence that much of the variation in recapture probabilities was explained by VHF effects; birds with tags also had higher recapture probabilities than those without tags. Any improvements to recapture probabilities tend to yield more precise and reliable survival estimates (Lebreton et al. 1992). However, both the short duration of this study and the small sample size for storm-petrels with VHF tags (and for all stormpetrels in 2009) may have produced biased, i.e., unrealistically high, and poorly estimated recapture and survival probabilities for those birds (e.g., Naef-Daenzer and Grüebler 2014). Hence, it is unclear whether survival was indeed higher because of better recapture probabilities for storm-petrels with VHF tags or as a consequence of limited data.

Storm-petrels were selected for VHF attachment to monitor reproductive-related activity around the colony. Therefore, it is also plausible that these birds had higher survival because they were established, successful breeders, whereas the rest of the sample would have included a mix of established breeders, recent recruits, and other adults. The latter would be a better representation of the general population; therefore, inferences regarding temporal variability and influence of covariates should be drawn from the majority of birds, which were not tagged.

\section{Effects of gulls on survival}

High predation rates could account for low survival at certain colonies where abundance of avian and/or mammalian predators is high (e.g., Stenhouse and Montevecchi 1999, Miles 2010). By nesting on offshore islands, storm-petrels can avoid mammalian predators to some extent, although both wild and domestic animals introduced to islands have had devastating impacts (McChesney and Tershy 1998, de León et al. 2006, Pollard 2008). Avian predators are not excluded from offshore islands, however, and often nest near or in storm-petrel colonies. In the St. Kilda island archipelago, Scotland, the storm-petrel population has declined by $54 \%$ in fewer than 10 years, with growing populations of Great Skuas that kill 21,000 adult storm-petrels per year (Newson et al. 2008, Miles 2010). With such a high number of adults being killed, the colony should be declining at a faster rate, but it is possible that it is being supplied with new breeders from larger colonies (e.g., from Iceland, Bicknell et al. 2012, 2013a).

Similar increases in predation of storm-petrels by gulls have been reported as well (Stenhouse and Montevecchi 1999). In the 1970s and 1980s, most gull populations increased in response to high food availability (e.g., human refuse and forage fish stock; Cotter et al. 2012). However, in the last couple of decades there have been significant reforms to handling of fisheries discards, and closures or changes to landfills (Cotter et al. 2012). This, in addition to moratoria on several major fish stocks in the North Atlantic, has led to shifts in gull (and skua, Bicknell et al. 2013b) diets, with increased predation of storm-petrels and other small seabirds (Stenhouse and Montevecchi 1999, Regular et al. 2013).

On Great Island in Newfoundland, the storm-petrel population remained relatively stable during the 1990 s, despite an average of $\sim 49,000$ storm-petrels killed per year by Great Black-backed and Herring gulls (Stenhouse et al. 2000, Robertson et al. 2006a). However, even with the uncertainty in any estimate of a burrownesting species' colony size, a significant decline has now been detected, with a $\sim 55 \%$ reduction of the Great Island breeding population between 1999 and 2012 (Wilhelm et al. 2015). Predation pressure on Great Island has apparently become too high to sustain the breeding population of storm-petrels, despite possible recruitment of new breeders from nearby Baccalieu Island. Interestingly, Baccalieu Island does not have a population of breeding gulls, nor does it suffer from introduced or invasive mammalian predators, factors that have possibly contributed to the large size and apparent stability of the storm-petrel population on the island.

Model-averaged effect size of gulls in our study suggests that presence of gulls reduced survival of storm-petrels on Bon Portage Island by 0.07 . This apparent effect may have been because of the small sample size and short duration of the study, and the CEs of this effect did include zero, but if real, a decline in survival of this magnitude would have biologically significant consequences for a population (e.g., reduced breeding lifespan, Wooller et al. 1992). It is not clear whether the reduction in survival probability would be because of direct mortality from gulls or from storm-petrels abandoning the study site. Alternatively, survival might be lower in plots occupied by gulls because the habitat of those plots is noticeably more open than that of the other plots, perhaps making it less suitable for nesting. Storm-petrels prefer to burrow in forested, as opposed to more exposed, habitats, in part because the soil in forested areas may be less compact and therefore ideal for digging burrows (Stenhouse and Montevecchi 2000). Maintenance of proper humidity levels required for chick development may also be easier to accomplish in habitats with better cover (Ricklefs et al. 1980, Huntington et al. 1996).

In addition to gulls, we estimate that two to three pairs of Great Horned Owls (Bubo virginianus) breed on Bon Portage Island, and examination of their pellets revealed that their diet consists almost exclusively of storm-petrels (I. L. Pollet, personal observation). Whether they pose a significant threat to the stormpetrels there remains unknown. Once again, additional years of data are needed to properly investigate influences of gulls and other predators on storm-petrel survival. It would be useful for future studies to include quantities of different species suspected to be depredating storm-petrels at this colony, as well as estimations of the number of storm-petrels killed annually by each predator species, and to assess whether this predation is on breeding or prospecting birds (Bonnaud et al. 2009, Bicknell et al. 2013a).

\section{Other factors affecting survival}

At a regional scale, the large distance between breeding and nonbreeding habitats (Pollet et al. 2014b) and highly pelagic behavior (Pollet et al. 2014a) mean that survival of storm-petrels is most likely influenced by a combination of factors, which are challenging to tease apart. Aside from predation, some of the main threats to storm-petrels are high levels of marine contaminants (e.g., mercury, Goodale et al. 2008, Bond and Diamond 2009), activities associated with oil and natural gas exploration (e.g., collisions with offshore oil and gas platforms, Ronconi et al. 2015; and contact with discharged residues from chronic and catastrophic hydrocarbon spills, Zabala et al. 2011), ingestion of plastic debris (Bond and Lavers 2013), and adverse climatic conditions (Boersma and Groom 1993, Soldatini et al. 2014). Moreover, recent tracking data during the breeding season 
showed that storm-petrels from Bon Portage Island and nearby Country Island, Nova Scotia (Fig. 1) forage in very different areas of the northwest Atlantic and generally ingest different prey types (Pollet et al. 2014a). Therefore, factors affecting survival of stormpetrels might be manifested in different ways even at breeding colonies that are relatively close to each other. Survival estimates for storm-petrels in the "no gull, no VHF" group are quite low (Fig. 2), even without effects of gull predation. Therefore, there are clearly other processes linked to their survival that have not been addressed by this study. Future survival analyses of stormpetrels from Bon Portage Island and other colonies should examine environmental variables, such as climate variability and food availability, as influences on survival.

\section{CONCLUSIONS}

Although estimating survival probabilities is generally considered a long-term research and monitoring investment, in the case of storm-petrels, monitoring adult survival probabilities may actually be a quicker and more effective technique to determine population status than repeated population estimates. Even though methodological improvements are continually being sought, estimating storm-petrel colony size, or the colony size of any burrow/crevice nesting species for that matter, is necessarily intensive work and the estimates tend to have wide confidence intervals (Major and Chubaty 2012, Sutherland and Dann 2012, Major et al. 2013, Wilhelm et al. 2015). Concerted efforts by researchers working at different colonies will be critical for determining factors associated with storm-petrel survival and identifying ways to mitigate low survival and its impact on the health of storm-petrel populations. As more data on vital rates are collected, population modeling could be used to determine the predicted population trend of storm-petrels at Bon Portage and other colonies, and to explore the efficacy of potential conservation and management actions. Integrated population models that include vital rates, population size, and population trends could prove to be particularly instructive, even in the face of limited data (Reid et al. 2013).

Although it is clear that more years of data are needed to refine survival and recapture estimates for storm-petrels on Bon Portage Island, three main points can be taken from this study: (1) VHF tags did not appear to have a negative effect on survival; (2) losses because of avian predators might be widespread across several breeding colonies; and (3) annual survival estimates were low, even after accounting for VHF tags and effects of nesting gulls. Consistently low survival over the last few years is cause for concern and warrants further attention. Storm-petrels are a widespread, yet cryptic, species, and dramatic population declines could go unnoticed unless they are routinely monitored throughout their range (Lormée et al. 2012). This study contributes to evidence that populations of storm-petrels could be facing regional declines.

Responses to this article can be read online at: http://www.ace-eco.org/issues/responses.php/771

\section{Acknowledgments:}

We are grateful to station manager Lee Adams for logistical support including transportation to and from Bon Portage Island and to Erika Holland, Madeline Sutton, and Zoe Crysler for their assistance in the field. We also thank April Hedd for survival estimates from Great Island, Sabina Wilhelm (Canadian Wildlife Service, Mount Pearl, Newfoundland) for information regarding the Baccalieu Island population, and Karissa Reischke for producing the study site map used in this paper. Finally, we thank Dr. Steffen Oppel and an anonymous reviewer for taking the time to provide helpful and comprehensive suggestions for improving this manuscript. All procedures were approved by the Acadia University Animal Care Committee (Protocol\#06-09). Funding was provided by the Nunavut General Monitoring Program, Natural Sciences and Engineering Research Council, Nova Scotia Habitat Conservation Fund (contributions from hunters and trappers), and Acadia University.

\section{LITERATURE CITED}

Anderson, D. R., K. P. Burnham, and G. C. White. 1994. AIC model selection in overdispersed capture-recapture data. Ecology 75:1780-1793. http://dx.doi.org/10.2307/1939637

Beck, J. R., and D. W. Brown. 1972. The biology of Wilson's Stormpetrel, Oceanites oceanicus (Kuhl), at Signey Island, South Orkney Islands. British Antarctic Survey Scientific Reports No. 69. British Antarctic Survey, London, UK.

Bicknell, A. W. J., M. E. Knight, D. Bilton, J. B. Reid, T. Burke, and S. C. Votier. 2012. Population genetic structure and longdistance dispersal among seabird populations: implications for colony persistence. Molecular Ecology 21:2863-2876. http://dx. doi.org/10.1111/j.1365-294X.2012.05558.x

Bicknell, A. W. J., M. E. Knight, D. T. Bilton, M. Campbell, J. B. Reid, J. Newton, and S. C. Votier. 2013a. Intercolony movement of pre-breeding seabirds over oceanic scales: implications of cryptic age-classes for conservation and metapopulation dynamics. Diversity and Distributions 1-9.

Bicknell, A. W. J., D. Oro, K. C. J. Camphuysen, and S. C. Votier. 2013b. Potential consequences of discard reform for seabird communities. Journal of Applied Ecology 50:649-658.

Blackmer, A. L., J. T. Ackerman, and G. A. Nevitt. 2004. Effects of investigator disturbance on hatching success and nest-site fidelity in a long-lived seabird, Leach's Storm-petrel. Biological Conservation 116:141-148. http://dx.doi.org/10.1016/S0006-3207 (03)00185-X

Boersma, P. D., and M. J. Groom. 1993. Conservation of stormpetrels in the North Pacific. Pages 70-81 in K. Vermeer, K. T. Briggs, K. H. Morgan, and D. Siegel-Causey, editors. The status, ecology, and conservation of marine birds of the North Pacific. Canadian Wildlife Service Special Publication. Canadian Wildlife Service, Ottawa, Ontario, Canada.

Bond, A. L., and A. W. Diamond. 2009. Mercury concentrations in seabird tissues from Machias Seal Island, New Brunswick, Canada. Science of the Total Environment 407:4340-4347. http:// dx.doi.org/10.1016/j.scitotenv.2009.04.018 
Bond, A. L., and J. L. Lavers. 2013. Effectiveness of emetics to study plastic ingestion by Leach's Storm-petrels (Oceanodroma leucorhoa). Marine Pollution Bulletin 70:171-175. http://dx.doi. org/10.1016/j.marpolbul.2013.02.030

Bonnaud, E., K. Bourgeois, E. Vidal, J. Legrand, and M. Le Corre. 2009. How can the Yelkouan shearwater survive feral cat predation? A metapopulation structure as a solution? Population Ecology 51:261-270.

Burger, A. E., and S. A. Schaffer. 2008. Application of tracking and data-logging technology in research and conservation of seabirds. Auk 125:253-264. http://dx.doi.org/10.1525/auk.2008.1408

Burnham, K. P., and D. R. Anderson, editors. 2002. Model selection and multimodel inference: a practical informationtheoretical approach. Springer-Verlag, New York, New York, USA. http://dx.doi.org/10.1007/b97636

Burnham, K. P., D. R. Anderson, G. C. White, C. Brownie, and K. H. Pollock. 1987. Design and analysis of fish survival experiments based on release-recapture data. American Fisheries Society Monograph 5. American Fisheries Society, Bethesda, Maryland, USA.

Carey, M. J. 2009. The effects of investigator disturbance on procellariiform seabirds: a review. New Zealand Journal of Zoology 36:367-377. http://dx.doi.org/10.1080/03014220909510161

Clobert, J., and J.-D. Lebreton. 1991. Estimation of demographic parameters in bird populations. Pages 75-104 in C. M. Perrins, J.D. Lebreton, and G. J. M. Hirons, editors. Bird population studies: relevance to conservation and management. Oxford University Press, Oxford, UK.

Cotter, R. A., J.-F. Rail, A. W. Boyne, G. J. Robertson, D. V. C. Weseloh, and K. G. Chaulk. 2012. Population status, distribution, and trends of gulls and kittiwakes breeding in eastern Canada, 1998-2007. Canadian Wildlife Service Occasional Paper No. 120. Canadian Wildlife Service, Ottawa, Ontario, Canada.

Cubaynes, S., P. F. Doherty, E. A. Schreiber, and O. Gimenez. 2011. To breed or not to breed: a seabird's response to extreme climatic events. Biology Letters 7:303-306. http://dx.doi. org/10.1098/rsbl.2010.0778

de León, A., E. Mínguez, P. Harvey, E. Meek, J. E. Crane, and R. W. Furness. 2006. Factors affecting breeding distribution of storm-petrels Hydrobates pelagicus in Orkney and Shetland. Bird Study 53:64-72. http://dx.doi.org/10.1080/00063650609461417

Erikstad, K. E., P. Fauchald, T. Tveraa, and H. Steen. 1998. On the cost of reproduction in long-lived birds: the influence of environmental variability. Ecology 79:1781-1788. http://dx.doi. org/10.1890/0012-9658(1998)079[1781:OTCORI]2.0.CO;2

Fiske, J. A., D. Gannon, and A. E. M. Newman. 2013. Effects of repeated investigator handling of Leach's Storm-petrel chicks on growth rates and the acute stress response. Journal of Field Ornithology 84:425-432. http://dx.doi.org/10.1111/jofo.12041

Gaston, A. J. 2011. Arctic seabirds: diversity, populations, trends, and causes. Pages 147-160 in R. T. Watson, T. J. Cade, M. Fuller, G. Hunt, and E. Potapov, editors. Gyrfalcons and Ptarmigan in a changing world. Volume 1. Peregrine Fund, Boise, Idaho, USA. http://dx.doi.org/10.4080/gpcw.2011.0201
Goodale, M. W., D. C. Evers, S. E. Mierzykowski, A. L. Bond, N. M. Burgess, C. I. Otorowski, L. J. Welch, C. S. Hall, J. C. Ellis, R. B. Allen, A. W. Diamond, S. W. Kress, and R. J. Taylor. 2008. Marine foraging birds as bioindicators of mercury in the Gulf of Maine. EcoHealth 5:409-425. http://dx.doi.org/10.1007/s10393-009-0211-7

Hovinen, J. E. H., J. Welcker, S. Descamps, H. Strøm, J. Jerstad, J. Berge, and H. Steen. 2014. Climate warming decreases the survival of the Little Auk (Alle alle), a high Arctic avian predator. Ecology and Evolution 4:3127-3138. http://dx.doi.org/10.1002/ ece 3.1160

Huntington, C. E., R. G. Butler, and R. A. Mauck. 1996. Leach's Storm-petrel (Oceanodroma leucorhoa). In A. Poole, editor. The birds of North America online. Cornell Lab of Ornithology, Ithaca, New York, USA. http://dx.doi.org/10.2173/bna.233

Kendall, W. L., R. J. Barker, G. C. White, M. S. Lindberg, C. A. Langtimm, and C. L. Peñaloza. 2013. Combining dead recovery, auxiliary observations and robust design data to estimate demographic parameters from marked individuals. Methods in Ecology and Evolution 4:828-835. http://dx.doi.org/10.1111/2041-210X.12077

Kendall, W. L., J. D. Nichols, and J. E. Hines. 1997. Estimating temporary emigration using capture-recapture data with Pollock's robust design. Ecology 78:563-578.

Laake J. L. 2013. RMark: an R interface for analysis of capturerecapture data with MARK. AFSC Processed Report 2013-01. Alaska Fisheries Science Center. National Oceanic and Atmospheric Administration, National Marine Fisheries Service, Seattle, Washington, USA.

Lebreton, J.-D., K. P. Burnham, J. Clobert, and D. R. Anderson. 1992. Modelling survival and testing biological hypotheses using marked animals: a unified approach with case studies. Ecological Monographs 62:67-118. http://dx.doi.org/10.2307/2937171

Lormée, H., K. Delord, B. Letournel, and C. Barbaud. 2012. Population survey of Leach's Storm-petrels breeding at Grand Colombier Island, Saint-Pierre and Miquelon Archipelago. Wilson Journal of Ornithology 124:245-252. http://dx.doi. org/10.1676/11-084.1

Major, H. L., A. L. Bond, I. L. Jones, and C. J. Eggleston. 2013. Stability of a seabird population in the presence of an introduced predator. Avian Conservation and Ecology 8(1): 2. http://dx.doi. org/10.5751/ACE-00564-080102

Major, H. L., and A. M. Chubaty. 2012. Estimating colony and breeding population size for nocturnal burrow-nesting seabirds. Marine Ecology Progress Series 454:83-90. http://dx.doi. org/10.3354/meps09663

McChesney, G. J., and B. R. Tershy. 1998. History and status of introduced mammals and impacts to breeding seabirds on the California Channel and northwestern Baja California islands. Colonial Waterbirds 21:335-347. http://dx.doi.org/10.2307/1521646

Miles, W. T. S. 2010. Ecology, behaviour and predator-prey interactions of Great Skuas and Leach's Storm-petrels at St. Kilda. Dissertation. University of Glasgow, Glasgow, UK.

Morse, D. H., and C. W. Buchheister. 1979. Nesting patterns of Leach's Storm-petrels on Matinicus Rock, Maine. Bird-Banding 50:145-158. http://dx.doi.org/10.2307/4512438 
Naef-Daenzer, B., and M. U. Grüebler. 2014. Effects of radio-tag characteristics and sample size on estimates of apparent survival. Animal Biotelemetry 2:1-9. http://dx.doi.org/10.1186/2050-3385-2-2

Newson, S. E., P. I. Mitchell, M. Parsons, S. H. O’Brien, G. E. Austin, S. Benn, J. Black, J. Blackburn, B. Brodie, E. Humphreys, D. Leech, M. Prior, and M. Webster. 2008. Population decline of Leach's Storm-petrel Oceanodroma leucorhoa within the largest colony in Britain and Ireland. Seabird 21:77-84.

O'Dwyer, T. W., W. A. Buttemer, and D. M. Priddel. 2006. Investigator disturbance does not influence chick growth or survivorship in the threatened Gould's Petrel Pterodroma leucoptera. Ibis 148:368-372. http://dx.doi.org/10.1111/ j.1474-919X.2006.00526.X

Oxley, J. R. 1999. Nesting distribution and abundance of Leach's Storm-petrel (Oceanodroma leucorhoa) on Bon Portage Island, Nova Scotia. Thesis. Acadia University, Wolfville, Nova Scotia, Canada.

Pollard, A. M. 2008. The effects of mammalian predators on a southern Oregon colony of Leach's Storm-petrels (Oceanodroma leucorhoa). Thesis. University of Oregon, Eugene, Oregon, USA.

Pollet, I. L., A. Hedd, P. D. Taylor, W. A. Montevecchi, and D. Shutler. 2014b. Migratory movements and wintering areas of Leach's Storm-petrels tracked using geolocators. Journal of Field Ornithology 85:321-328.

Pollet, I. L., R. A. Ronconi, I. D. Jonsen, M. L. Leonard, P. D. Taylor, and D. Shutler. 2014a. Foraging movements of Leach's Storm-petrels Oceanodroma leucorhoa during incubation. Journal of Avian Biology 45:305-314.

Pollock, K. H., and R. Alpizar-Jara. 2005. Classical openpopulation capture-recapture models. Pages 36-57 in S. C. Amstrup, T. L. McDonald, and F. J. Manly, editors. Handbook of capture-recapture analysis. Princeton University Press, Princeton, New Jersey, USA. http://dx.doi.org/10.1515/9781400837717.36

Pradel, R., O. Gimenez, and J. D. Lebreton. 2005. Principles and interest of GOF tests for multistate capture-recapture models. Animal Biodiversity and Conservation 28:189-204.

Pradel, R., J. E. Hines, J.-D. Lebreton, and J. D. Nichols. 1997. Capture-recapture survival models taking account of transients. Biometrics 53:60-72. http://dx.doi.org/10.2307/2533097

Quillfeldt, P., R. A. R. McGill, R. W. Furness, E. Möstl, K. Ludynia, and J. F. Masello. 2012. Impact of miniature geolocation loggers on a small petrel, the Thin-billed Prion Pachyptila belcheri. Marine Biology 159:1809-1816. http://dx.doi.org/10.1007/ s00227-012-1971-0

R Development Core Team. 2014. R: a language and environment for statistical computing. R Foundation for Statistical Computing, Vienna, Austria. [online] URL: http://www.R-project.org/

Regular, P. M., W. A. Montevecchi, A. Hedd, G. J. Robertson, and S. I. Wilhelm. 2013. Canadian fishery closures provide a largescale test of the impact of gillnet bycatch on seabird populations. Biology Letters 9:20130088. http://dx.doi.org/10.1098/rsbl.2013.0088

Reid, T., M. Hindell, J. L. Lavers, and C. Wilcox. 2013. Reexamining mortality sources and population trends in a declining seabird: using Bayesian methods to incorporate existing information and new data. PLoS ONE 8:e58230. http://dx.doi. org/10.1371/journal.pone.0058230

Reynolds, R. T., G. C. White, S. M. Joy, and R. W. Mannan. 2004. Effects of radiotransmitters on Northern Goshawks: do tailmounts lower survival of breeding males? Journal of Wildlife Management 68:25-32.

Ricklefs, R. E., S. C. White, and J. Cullen. 1980. Energetics of postnatal growth in Leach's Storm-petrel. Auk 97:566-575.

Robertson, G. J., J. Russell, R. Bryant, D. A. Fifield, and I. J. Stenhouse. 2006a. Size and trends of Leach's Storm-petrel Oceanodroma leucorhoa breeding populations in Newfoundland. Atlantic Seabirds 8:41-50.

Robertson, G. J., A. E. Storey, and S. L. Wilhelm. 2006b. Local survival rates of common murres breeding in Witless Bay, Newfoundland. Journal of Wildlife Management 70:584-587.

Ronconi R., A., K. A. Allard, and P. D. Taylor. 2015. Bird interactions with offshore oil and gas platforms: review of impacts and monitoring techniques. Journal of Environmental Management 147:34-45. http://dx.doi.org/10.1016/j.jenvman.2014.07.031

Sanz-Aguilar, A., B. Massa, F. Lo Valvo, D. Oro, E. Minguez, and G. Tavecchia. 2009. Contrasting age-specific recruitment and survival at different spatial scales: a case study with the European Storm petrel. Ecography 32:637-646. http://dx.doi.org/10.1111/ j.1600-0587.2009.05596.x

Schreiber, E. A., and J. Burger, editors. 2001. Biology of marine birds. CRC, New York, New York, USA. http://dx.doi. org/10.1201/9781420036305

Sklepkovych, B. O., and W. A. Montevecchi. 1989. The world's largest known nesting colony of Leach's Storm-petrels on Baccalieu Island, Newfoundland. American Birds 43:38-42.

Soldatini, C., Y. V. Albores-Barajas, B. Massa, and O. Gimenez. 2014. Climate driven life histories: the case of the Mediterranean Storm petrel. PLOS ONE 9:e94526. http://dx.doi.org/10.1371/ journal.pone.0094526

Stenhouse, I. J., and W. A. Montevecchi. 1999. Indirect effects of the availability of capelin and fishery discards: gull predation on breeding storm-petrels. Marine Ecology Progress Series 184:303-307. http://dx.doi.org/10.3354/meps184303

Stenhouse, I. J., and W. A. Montevecchi. 2000. Habitat utilization and breeding success in Leach's Storm-petrel: the importance of sociality. Canadian Journal of Zoology 78:1267-1274. http://dx. doi.org/10.1139/z00-065

Stenhouse, I. J., G. J. Robertson, and W. A. Montevecchi. 2000. Herring Gull Larus argentatus predation on Leach's Stormpetrels Oceanodroma leucorhoa breeding on Great Island, Newfoundland. Atlantic Seabirds 2:35-44.

Sutherland, D. R., and P. Dann. 2012. Improving the accuracy of population size estimates for burrow-nesting seabirds. Ibis 154:488-498. http://dx.doi.org/10.1111/j.1474-919X.2012.01234. $\mathrm{x}$

Weimerskirch, H., and P. Jouventin. 1987. Population dynamics of the Wandering Albatross, Diomedea exulans, of the Crozet 
Islands: causes and consequences of the population decline. Oikos 49:315-322. http://dx.doi.org/10.2307/3565767

White, G. C., and K. P. Burnham. 1999. Program MARK: survival estimation from populations of marked animals. Bird Study 46: S120-S139. http://dx.doi.org/10.1080/00063659909477239

Wilhelm, S. I., J. Mailhiot, J. Arany, J. W. Chardine, G. J. Robertson and P. C. Ryan. 2015. Update and trends of three important seabird populations in the western North Atlantic using a geographic information system approach. Marine Ornithology, 43, in press.

Wooller, R. D., J. S. Bradley, and J. P. Croxall. 1992. Long-term population studies of seabirds. Trends in Ecology \& Evolution 7:111-114. http://dx.doi.org/10.1016/0169-5347(92)90143-Y

Zabala, J., I. Zuberogoitia, J. A. Martínez-Climent, and J. Etxezarreta. 2011. Do long lived seabirds reduce the negative effects of acute pollution on adult survival by skipping breeding? A study with European Storm Petrels (Hydrobates pelagicus) during the "Prestige" oil-spill. Marine Pollution Bulletin 62:109-115. http://dx.doi.org/10.1016/j.marpolbul.2010.09.004 